While it may well be that the economic advantages claimed for the North Wales hydro-electricity schemes are not so great as imagined, this is not the point on which the Protection Committee in its campaign deserves the support of all who take seriously the preservation of the finest mountain scenery of Wales. It is rather the point on which Dr. Julian Huxley insists : that failure in a national park area to make the preservation of natural beauty the supreme national interest is not only to repudiate the very conception and meaning of a national park but also to threaten the whole principle underlying the planned utilization of our limited resources. We must to the best of our judgment designate the social functions which in particular areas are to be paramount, and then see that those functions are, in fact, supreme.

More, therefore, than the future of the Snowdonia National Park is at stake in the present controversy over the Welsh power schemes, and an even keener interest will accordingly be taken in the nature of the planning body which Sir Patrick Duff indicated on May 4 was expected to be set up by the National Parks Commission for the Peak District National Park before the end of the year. Sir Patrick, who, with members of the Commission, afterwards spent three days surveying the Peak district with the view of defining the boundaries of the Park, would not commit himself at the present stage on the form that body would take. He emphasized, however, that the National Parks Act laid down clearly that the planning authority should be a joint board unless the county authorities could show good cause against it. That may well be a significant reference, and it should be noted and welcomed by all who have at heart the real meaning and purpose of the national parks, and are concerned that neither the nature of the planning authorities established nor controversy between alternative plans or schemes like those of the British Electrical Authority and the North Wales (Hydro-electricity) Protection Committee should obscure the real issues or impede the achievement of the full purpose of the National Parks Act. Meanwhile, evidence is already available that the National Parks Commission is addressing itself to its tasks with imagination as well as energy, and that it merits strong government support and clear public understanding.

\section{PREHISTORY OF AERONAUTICS}

\section{Voyages to the Moon}

By Marjorie Hope Nicolson. Pp. xvii $+297+8$ plates. (New York: The Macmillan Company; London : Macmillan and Co., Ltd., 1948.) 20s. net.

7 HIS book is not an easy one to classify, and the title is somewhat misleading, as it does not do justice to the more serious work contained. The author defines her scope as "tracing the idea of flight through the literature of the two centuries immediately preceding man's conquest of the air" (namely, the two hundred years before the first balloon ascents in 1783) and, more particularly, as treating with "the cosmic voyage as English readers knew it in the 17th and 18th centuries". The book is based on a series of lectures delivered in 1946 and is illustrated by engravings contemporary with the period under review.

Miss M. H. Nicolson (who enjoys a distinguished academic career in America) may thus appear to have joined the ranks of the historians of aeronautics; but the book is actually a study of literature, and the impact of science upon it, rather than an independent investigation of the development of the idea of human flight. This distinction, though perhaps a fine one, is important, for it constitutes the difference between the seientific and the non-scientific methods of approach to this subject. For example, it impels the author to cite (in her "subterranean" group) Lewis Carroll's "Alice in Wonderland" as "the greatest of English cosmic voyages", whereas it has little relevance, if any, to the problem of human flight. She might as easily have included "Through the Looking Glass" in her "voyages, planetary" ; but she makes only bare mention in passing.

The fundamental basis of the idea of man's flight was, of course, the natural phenomenon ; it was the inspiration and the only model, so that it is doubtful whether man would ever have conceived flight had Nature not provided the pattern. Hence, a scientific study of the development of the idea should include an appreciation of the natural sources and their relationship. This is not to say that Miss Nicolson's literary method has no value in aeronautical studies ; on the contrary, it serves to illuminate the long period of aspiration which preceded that of the imitation of Nature and scientific enunciation of principles. In her interpretation of the classical literature of flight, she has drawn on and received inspiration from J. E. Hodgson and the late Berthold Laufer, whose writings-as she gracefully emphasizes in her bibliography-are unquestionably the most comprehensive and valuable in the English language. But she has not, apparently, consulted the contemporary works of Charles Dollfus in France.

The author's history of that which she terms "cosmic speculation" embraces the writings of such as Lucian, Cicero, Plutarch, Rabelais, Cervantes, Milton, Donne, Swedenborg, Rousseau, Thomas Gray, Samuel Johnson and the Jesuit natural philosopher, Kircher. These form the classical background to her thesis, which is, broadly speaking, that the history of the idea of flight does not date from, say, the scientific speculations of Leonardo da Vinci but from ancient literary traditions touched by the "new philosophy" of the sixteenth and seventeenth centuries-a contention which will be generally accepted. Miss Nicolson has many other sources for her investigation and has included some moderns actually outside her period, such as Poe, Jules Verne, H. G. Wells and (as already remarked) Lewis Carroll, who are examined as exponents of the imaginary voyage.

An immense amount of literary research has gone into the making of this book, and it bears the mark of scholarship. The annotated bibliographies of primary and secondary materials in various languages (some thirty pages) alone make it worth a place among aeronautical works of reference. With the excellent index, it is possible for the reader to review conveniently the classical allusions to flight, which after all-and irrespective of the fact that they are flights of fancy - are the strongest evidence of man's primeval and enduring desire to emulate Nature in that accomplishment naturally denied to him.

M. J. B. DAVY 